\title{
Analysis of Liquidity-Study on Indian Mid-Cap Stocks
}

\author{
Gaurav Kumar ${ }^{1} \&$ Arun Kumar Misra ${ }^{1}$ \\ ${ }^{1}$ Finance and Accounting, Indian Institute of Technology (IIT), Kharagpur, India \\ Correspondence: Gaurav Kumar, PhD Research Scholar, Finance and Accounting, Indian Institute of Technology \\ (IIT), Kharagpur, India. E-mail: gauravkumar@iitkgp.ac.in
}

Received: July 7, 2015

Accepted: July 27, 2015

Online Published: September 25, 2015

doi:10.5539/ijef.v7n10p112

URL: http://dx.doi.org/10.5539/ijef.v7n10p112

\begin{abstract}
Liquidity is the pre-condition for a well-functioning and efficient market. Liquidity can be perceived, but difficult to measure due to its multi-dimensional characteristics. Studies have discussed various characteristics of liquidity and its influencing power on return and asset pricing. The article has considered Indian MidCap stocks and measured its liquidity using Amihud and trading volume as proxies. It has found Indian MidCap stocks have varying degree of liquidity. During the intraday, MidCap stocks have L-shaped liquidity pattern. The article observed that P-E ratio, P-B ratio, Dividend Yield and Index of Industrial Production are the significant determinants of liquidity. The article has estimated liquidity betas and carried out Granger non-causality test to articulate its relation with CAPM beta. The article has also found stability of liquidity beta across MidCap stocks. The liquidity betas of MidCap stocks have time-varying volatility. Relative Strength Index (RSI) and Change in Trading Volume are exogenous variables in explaining the time-varying volatility of beta. The study observed that MidCap stocks are claiming liquidity premium and liquidity premium is influencing the asset pricing along with WML, HML and EMR factors.
\end{abstract}

Keywords: liquidity proxies, liquidity pattern, liquidity premium, liquidity beta, carhart four factor model

\section{Introduction}

Liquidity of a stock is generally defined as the ability to trade large volumes with minimal price impact, cost and delay. While this definition itself is simple, a universally acceptable measure of liquidity continues to be elusive, resulting in the presence of diverse measures. Tightness, Immediacy, Depth, Breadth, and Resiliency are the primary characteristics of liquidity. The recent financial crisis highlighted the role of liquidity as a precondition for well-functioning and efficient markets. Findings about the properties of common determinants of liquidity will also help investors to decide on their liquidity exposures. With an improved knowledge of factors that influence liquidity, investor confidence will increase, leading to more efficient corporate resource allocation (Chordia et al., 2003). Literature highlights the role of liquidity in making various corporate and investment decisions (Gatchev et al., 2005). Lipson and Mortal (2009) examined the relation between equity market liquidity and capital structure and reported that firms with more liquid equity prefer equity financing.FII as a factor in determining trading activity and liquidity of stock markets is discussed in literature (Liu et al., 2009; Wang, 2007; Wei, 2010). A wide array of literature has studied the linkage between liquidity and stock returns in many countries (Faff et al., 2010; Narayan \& Zheng, 2011). Investors are exposed to liquidity risk when the stock changes ownership making it a priced factor in making investment decisions (Jacoby et al., 2000; Acharya \& Pederson, 2005; Nguyun et al., 2007).

The goal of this paper is to examine the liquidity of MidCap stocks listed on NSE using various liquidity measures; namely Amihud (2002) illiquidity ratio, Trading Volume, Spread and Depth. MidCap stocks are relatively more risky than large cap and less risky in comparison to small cap as investment options. Investors in emerging economies prefer MidCap stocks in their portfolio as with a liberalised industrial and services sectors, the chances of finding mid-level companies with potential to becoming large corporations are much better than the developed economies like the US and Europe.

With the above brief introduction, the study has initiated extensive review of literature with primary focus on the concept of liquidity, proxies and intraday patterns of liquidity, determinants of liquidity and its implications on asset pricing. 


\section{Literature Review}

\subsection{Liquidity Proxy and Pattern}

According to Amihud and Medelson (1986) a liquid markets tend to exhibit five characteristics: (i) tightness; (ii) immediacy; (iii) depth; (iv) breadth; and (v) resiliency. Tightness refers to low transaction costs, such as the difference between buy and sell prices, like the bid-ask spread in quote driven markets, as well as implicit costs. Immediacy represents the speed with which orders can be executed. Depth refers to the existence of abundant orders. Breadth means that orders are both numerous and large in volume with minimal impact on prices. Resiliency is the characteristic of the markets in which new order flow quickly to correct order imbalances. Market liquidity is impossible to capture with only one measure due to its multidimensional features.

An understanding of the behavior pattern of various liquidity proxies gives us an idea about the variations in the liquidity of stocks and the costs involved in trading in such stocks (Amihud and Mendelson, 1980; Acharya and Pedersen, 2005). Most of the existing literature gauging liquidity has focused on different dimensions of liquidity of individual financial assets. Baker (1996) concluded that there is no single unambiguous, theoretically correct or universally accepted definition of liquidity. Sarr and Lybek (2002) opine that there is no universally accepted measure to determine a market's degree of liquidity because of market specific factors and peculiarities. Bernstein (1987) examined different measures of stock liquidity and concluded that liquidity and efficiency are not compatible to each other. Amihud and Mendelson (1986) lay emphasis on the direct relationship between liquidity and cost of capital. High liquid markets are attractive to investors because of the easy exit from firm's ownership. Hui and Heubel (1984) hypothesizes that part of unsystematic risk represents liquidity of stock. Holden and Trzcinka (2009) conclude the Amihud measure does a better job than most other measures at capturing liquidity, and is robust to regime changes such as the change in minimum tick size to decimals. Illiquidity (ILLIQ) is much more precise as a measure of liquidity than other measures. Sioud et al. (2006) studied the dynamics of liquidity associated with the stocks listed on Tunisian stock market and concluded that shocks are absorbed more quickly for frequently traded stocks than for infrequently traded ones. Intraday pattern in stock markets has attracted much research attention. This importance is due to the existence of intraday regularities in stock market that contests the Efficient Markets Hypothesis. Köksal (2012) studies intraday patterns of various liquidity proxies on Istanbul Stock Exchange (ISE) using limit order book. This study reported spreads follow an L-shaped pattern whereas returns, number of trades and volume follow a U-shaped pattern. Tissaoui (2012) investigates the intraday pattern of trading activity, liquidity and return volatility in Tunisian Stock Exchange (TSE) and found U-shaped patterns. Krishnan and Mishra (2013) investigates intraday liquidity patterns on the National Stock Exchange (NSE) of India and reported that many liquidity proxies have U-shaped pattern.

\subsection{Determinants of Liquidity}

Jacoby and Zheng (2010) studied the empirical relationship between ownership dispersion and market liquidity. The study found that higher ownership dispersion improves market liquidity. Baber et al. (2012) studied the relationship between-Institutional Investors, Liquidity, and Liquidity Risk. They find that institutional ownership generally predicts larger stock liquidity, and so does concentrated ownership with mutual funds and hedge funds. Yaghoobnezhad et al. (2011) studied of relationship between Institutional Ownership and Stock Liquidity in Tehran Stock Exchange. The results of the study indicate a significant positive relationship between the percentage of institutional ownership and stock liquidity. Næs (2004) found a weaker negative relation between spreads and insider holdings in Norway stock exchange. Sharma (2005) studied ownership structure and stock liquidity on Indian stock market and found that the promoters' shareholding is not a statistically significant variable in explaining the determinants of liquidity in both Nifty stocks and Nifty junior stocks. Keim and Blume (2012) provide evidence that institutional participation in the U.S. stock market explains the cross-sectional variation in stock market illiquidity. Kim and Verrecchia (1994) study the relationship between earnings announcements, trading volume and liquidity. As per given model, earnings announcements increase the information asymmetry, which in turn leads to reduced liquidity in an imperfect market. Kumar et al. (2001) studied the impact of international listings like ADR and GDR on liquidity of Indian firm's underlying domestic shares. GDR listings are associated with enhanced liquidity while ADR listings (in most cases) are associated with reduced liquidity of the shares of domestic firm. Chordia, Roll and Subrahmanyam (2001) observed that liquidity and trading activity is influenced by market returns, its volatility, short-term and long-term interest rates. Macroeconomic news like GDP, unemployment rate also impact liquidity at the time of announcements. Gatchav et al. (2005) mentioned that the payout policy of the firm is related to the liquidity of its common stock. In illiquid markets investors will have greater demand for cash dividends from the stocks they hold. Larch and Peter (2011) sheds light on the actual impact of monetary policy on stock liquidity and thereby addresses its role 
as a determinant of commonality in liquidity. Ding et al. (2013) empirically studied the relationship between Foreign Institutional Investors (FII) and stock market liquidity in China. The results reveal that with greater participation of foreign institutions stock market liquidity improves on both the Shanghai and Shenzhen exchanges. Goyenko \& Ukhov (2009) document strong evidence for the U.S. monetary policy in influencing liquidity for the period 1962 to 2003. Chordia et al. (2005) report only modest predictive power of monetary policy for stock market liquidity. Söderberg (2008) studies the influence of 14 macroeconomic variables on the market liquidity of three Scandinavian stock exchanges between 1993 and 2005 and also provides mixed evidence.

\subsection{Risk and Return and Liquidity}

Amihud and Mendelson (1986) analyze the effect of bid ask spread or illiquidity on asset pricing i.e. how liquidity affects stock returns. Bali et al. (2013) revealed that stock market under-reacts to liquidity shocks on NYSE, AMEX and NASDAQ exchanges. Investor inattention and illiquidity both drive this under reaction. Bali et al. (2013) finds that immediate liquidity shocks have positive impact on contemporaneous stock returns. They examined double sorted portfolios using Fama-MacBeth regressions to confirm the highly significant relationship between liquidity shocks and future returns using large set of control variables example level of illiquidity, systematic liquidity risk, size, book to market, price momentum etc. Pastor and Stambaugh (2001) find evidence that market-wide liquidity is a key state variable for asset pricing on NYSE, AMEX and NASDAQ Chang et al. (2009) analyzed the effect of liquidity on stock returns on Tokyo Stock Exchange (TSE) and found that the liquidity level has strong significant impact on stock return in different phases of business cycle. In case of Shanghai Stock Exchange (SHSE) and the Shenzhen stock exchange (SZSE), Narayan and Zheng (2011) found negative impact of liquidity on returns. Chordia et al. (2001) demonstrate the importance of trading activity related variables in the cross section of expected returns. Strong negative relationship is reported between both the level of liquidity, its volatility and expected returns. Chordia et al. (2001) argues that their finding is puzzling as risk averse investors require premium for holding volatile liquid stocks.

\subsection{Liquidity and Assets Pricing}

Acharya and Pedersen (2005) explained the economic significance of liquidity risk mentioned that liquidity risk explains about $1.1 \%$ of cross-sectional returns. Vu et al. (2014) examine the pricing of liquidity risk in the Australian market, using data from 1991-2010 and found strong evidence of co-movements of stock returns and market illiquidity and stock illiquidity and market returns. Hagstromer et al. (2013) investigates the relation between illiquidity and illiquidity risk and the size, value and momentum anomalies for US stocks. They found a very strong correlation between Fama-French size betas and illiquidity and a fairly strong correlation between Fama-French value betas and illiquidity risk betas. However, Carhart's momentum beta has high negative correlation with betas both for illiquidity level and risk. Eleswarapu and Reinganum (1993) empirically investigate the seasonal behavior of the liquidity premium in asset pricing and observed that liquidity premium is reliably positive only during the month of January. Martínez et al. (2005) empirically studied the explanatory power of systematic liquidity on asset pricing on Spanish stock market and concluded that market wide liquidity is a plausible factor to be included in asset pricing models. Hubers (2012) studies the relationship between asset prices and liquidity on London Stock Exchange (LSE) reported significance of liquidity betas.

\section{Objectives of the Study}

Looking at the literature review and above discussion, there is a requirement of formal approach to examine liquidity indicators and proxies, its determinants and implications of liquidity on asset pricing. The study focuses on following objectives:

1) Assessment of liquidity using both high and low frequency data at CNX Midcap stocks.

2) Estimation of liquidity beta and study its stability and causal relation with CAPM Beta.

3) Establish the relative importance of various firm specific factors and macroeconomic factors as determinants of liquidity.

4) Empirically examined the significance of liquidity premium as a factor in Fama-French asset pricing model.

\section{Empirical Design}

\subsection{Proxy and Indicators of Liquidity}

The study has used both low frequency day-end data and high frequency intra-day data to estimate following proxies for liquidity. 
Low frequency proxies employed in the study are as follows:

a) Amihud (2002) illiquidity ratio: This proxy provides a measure of price impact. The Amihud ratio is regarded as one of the best price impact measure constructed from low frequency data (Hasbrouck, 2006; Goyenko, Holden and Trzcinka, 2009). For individual stock, the illiquidity ratio (ILLIQ $\left.Q_{i d}\right)$ is given by:

$$
I L L I Q_{i d}=\frac{\left|R_{i d}\right|}{R V O L_{i d}}
$$

Where $R_{i d}$ is the return on stock $i$ on day $d$ and $\mathrm{RVOL}_{\mathrm{id}}$ is the Rupee volume of trading volume on the same day.

b) Trading Volume $\left(Q_{t}\right)$ : It is number of shared traded per time unit (e.g. day). Volume related measure captures the depth dimension of liquidity.

$$
Q_{t}=\sum_{i=1}^{N_{t}} q_{i}
$$

Where, $\mathrm{N}_{\mathrm{t}}$ denotes the number of trades between $\mathrm{t}-1$ and $\mathrm{t}, \mathrm{q}_{\mathrm{i}}$ is the number of shares of trade $\mathrm{i}$.

High frequency proxies based on Chordia, Roll and Subrahmanyam $(2000,2001)$ are employed in the study. These are as follows:

\section{c) Quoted Spread}

$$
Q S P R=\left|P_{A}-P_{B}\right|
$$

Where $\mathrm{P}_{\mathrm{A}}$ is the lowest ask price and $\mathrm{P}_{\mathrm{B}}$ is the highest bid price.

d) Depth

$$
D E P=\frac{\left(Q_{A}+Q_{B}\right)}{2}
$$

The study aims to discern and trace intraday liquidity movements in Indian stock market by studying high frequency data which is sampled at an interval of 30 minutes. This will help in understanding market microstructure in order to explain the existence of observed patterns.

\subsection{Liquidity Beta}

Following Watanabe and Watanabe (2008), the study will find out sensitivity of return to liquidity or 'liquidity $\beta$ ' using the following regression equation:

$$
R_{i}=\alpha_{i}+\beta_{i} L i q_{i}+\epsilon_{i}
$$

Where $R_{i}$ is the return, $\beta_{i}$ is the liquidity beta and $\operatorname{Liq}_{i}$ is the liquidity of the stock $i$.

This equation is run for each stock on monthly basis using daily data and to obtain each stock's monthly $\beta$. For each industry, the stability of $\beta$ will be tested through Augmented Dicky Fuller (ADF) test.

To verify the existence of a unit root in an $A R(p)$ process, the test is $H_{0}: \beta=1$ vs. $H_{\alpha}: \beta<1$ using the regression.

$$
x_{t}=c_{t}+\beta x_{t-1}+\sum_{i=1}^{p-1} \emptyset_{i} \Delta x_{t-1}+e_{t}
$$

Where $c_{t}$ is a deterministic function of time index $t$ and $\Delta x_{j}=x_{j}-x_{j-1}$ is the differentiated series of $x_{t}$. In practice, $c_{t}$ can be zero or a constant or $c_{t}=\omega_{0}+\omega_{1}$ t. The $t$ ratio of $\widehat{\beta}-1$,

$$
A D F=\frac{\widehat{\beta}-1}{\operatorname{std}(\widehat{\beta})}
$$

Where denotes the least-squares estimate of $\beta$, is the well known Augmented Dickey-Fuller (ADF) unit root test.

The volatility clustering of 'liquidity $\beta$ ' will be empirically examined using following ARCH model.

$$
\begin{gathered}
a_{t}=\sigma_{t} \epsilon_{t} \\
\sigma_{t}^{2}=\alpha_{0}+\alpha_{1} a_{t-1}^{2}+\cdots+\alpha_{m} a_{t-m}^{2}
\end{gathered}
$$

Where $\left\{\epsilon_{\mathrm{t}}\right\}$ is a sequence of independent and identically distributed (iid) random variables with mean zero and variance $1, \alpha_{0}>0$, and $\alpha_{i} \geq 0$ for $\mathrm{i}>0$. 


\subsection{Determinants of Liquidity}

As per the literature review, following macro-economic and firm specific factors would be used as explanatory variables.

a) Index of Industrial Production (IIP)

b) GSEC- 10 years yield (YLD)

c) Net FII Inflow (NFII)

Firm Specific Factors:

a) $\mathrm{PE}$ ratio (PE)

b) $\mathrm{PB}$ ratio $(\mathrm{PB})$

c) Dividend yield (DIY)

A panel data regression will be estimated using Amihud illiquidity measure as dependent variable and above mentioned factors as independent variables.

$$
L_{i t}=\alpha_{i 0}+C_{i 1} I I P_{t-k}++C_{i 2} Y L D_{t-k}+C_{i 3} N F I I_{t-k}+C_{i 4} P E_{t-k}+C_{i 5} P B_{t-k}+C_{i 6} D I Y_{t-k}+\epsilon_{i t}
$$

Where $t-k$ represents the lag length and $\epsilon_{i t}$ represents the error term in regression.

\subsection{Risk, Return and Liquidity Premium}

Granger non-causality test is carried out on the time series data structure of proxy of liquidity against its returns. This is done in order to understand the causal relationship if any, between liquidity and return. Similarly, Granger non-causality test also carried out between liquidity beta and CAPM beta.

Stocks are sorted in decreasing order of liquidity and quantile portfolios are formed with one month formation and one month holding period. With two years data set of 30 companies, study has 36 portfolios each year. The return differential between the highest and lowest liquidity portfolio represents "Liquidity Hedging Portfolio (LHP)" return. This is as per the study of Fu et al. (2012). The study extended Fama-French four factor model by including LHP and empirically verify the same through the time series regressions. Identified sample stocks are sorted on the basis of market capitalization, book value, idiosyncratic volatility and returns. Sorting on the basis of market capitalization provides SMB factors. Similarly sorting on the basis of book value provides the HML factor. Momentum factor is estimated by sorting the portfolio on the basis of return. The return differential between the highest and lowest liquidity portfolio represents "Liquidity Hedging Portfolio (LHP)" return and it is the fifth factor. In addition to the four factors, Carhart (1997) model is augmented by a liquidity factor.

$$
R P_{j t}-R F_{t}=a_{j}+b_{j}\left[R M_{j}-R F_{t}\right]+s_{j} S M B_{t}+H_{h} H M L_{t}+m_{j} M O M_{t}+i_{j} L I Q_{t}+e_{j t}
$$

Where, $R P$ is the return for portfolio $j, R F$ is the monthly risk-free rate; $R M$ is the value-weighted market monthly return; $S M B, H M L, M O M$ and $L I Q$ are the factor-mimicking portfolios for size, book-to-market, momentum and liquidity.

\subsection{Data and Sample Selection}

The study has selected 30 companies from the CNX-MidCap of National Stock Exchange of India. Mid-Cap stocks generally have liquidity problems in India. Stocks selection would be as per following criteria:

a) Stocks which are highly priced and have high trading volume turnover should be excluded from the data set.

b) Stock with very low price (pity stocks) and low trading volume should be excluded.

c) Dataset should represent stocks from all sectors of the economy.

d) Stocks should have 120 days of trading in a year.

e) Stocks with missing values of dividend yield, book to market ratio, last periods annual returns, profit margin, leverage ratio, and earnings to price ratio are excluded.

The data set have representation of stocks from banking and finance, consumer goods, infrastructure, manufacturing, media, entertainment, healthcare, pharmaceutical, automobile and chemicals.

\section{Results \& Discussion}

\subsection{Liquidity Proxies, Patterns \& Stability}

Sector specific liquidity has been analysed using Trading volume and Amihud proxy. The estimation indicates 
Pharma \& Chemicals have the highest liquidity over the period and Consumer goods sector is the least liquid sector. This trend has been observed both in case of Trading volume and Amihud proxy (Figure $1 \& 2$ ).

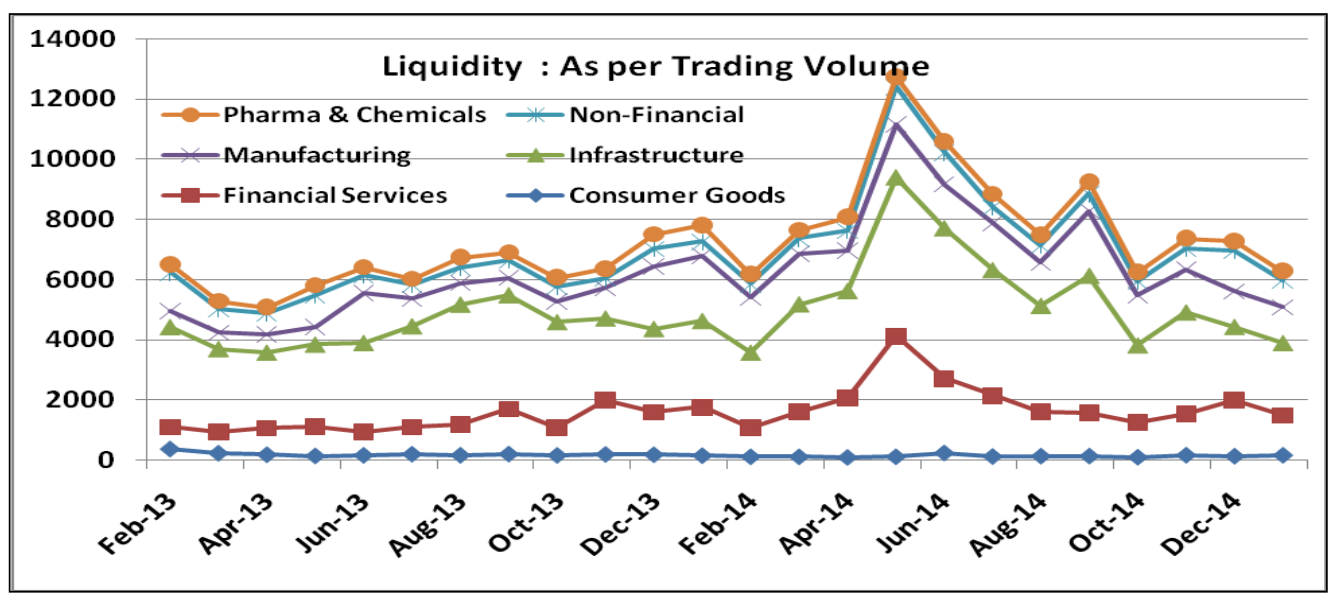

Figure 1. Liquidity as per trading volume

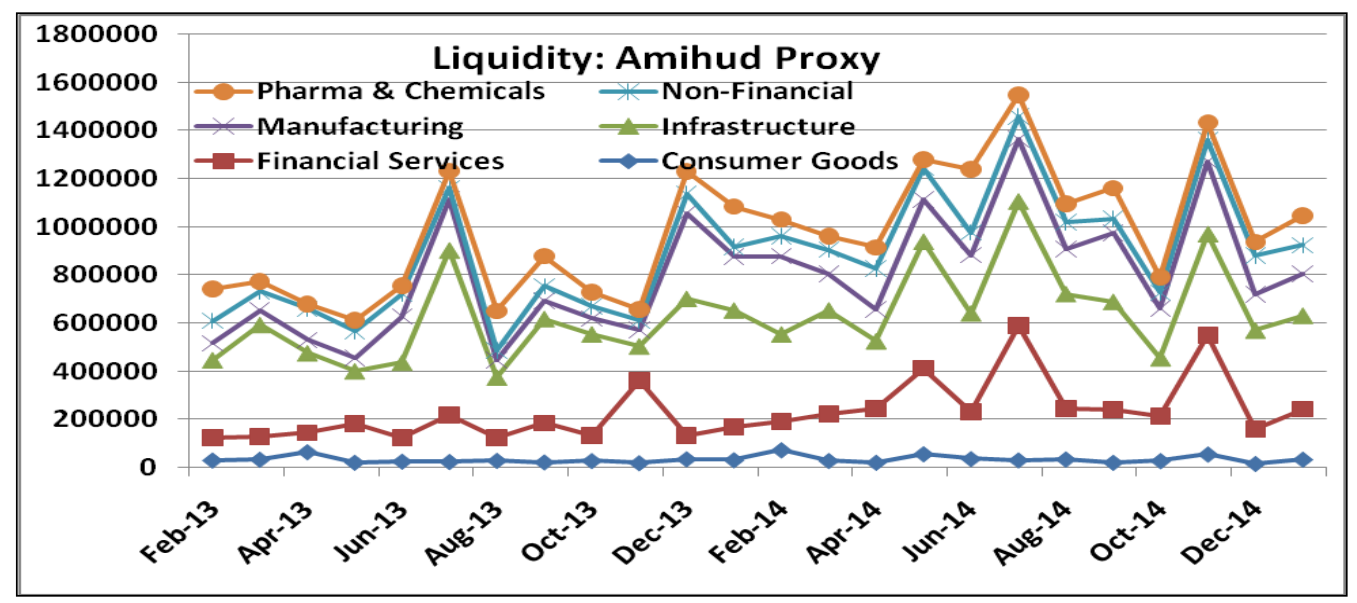

Figure 2. Liquidity as per amihud proxy

As per high frequency data (intraday Bid-Ask spread), the 30 stocks of MidCap indicates "L-shaped" pattern which has been found by other studies in different countries \{Guo and Tian (2005) on Shanghai Stock Exchange; Köksal (2012) on Istambul Stock Exchange\}. The depth, as an indicator of liquidity, indicates varying degree of liquidity during the day.

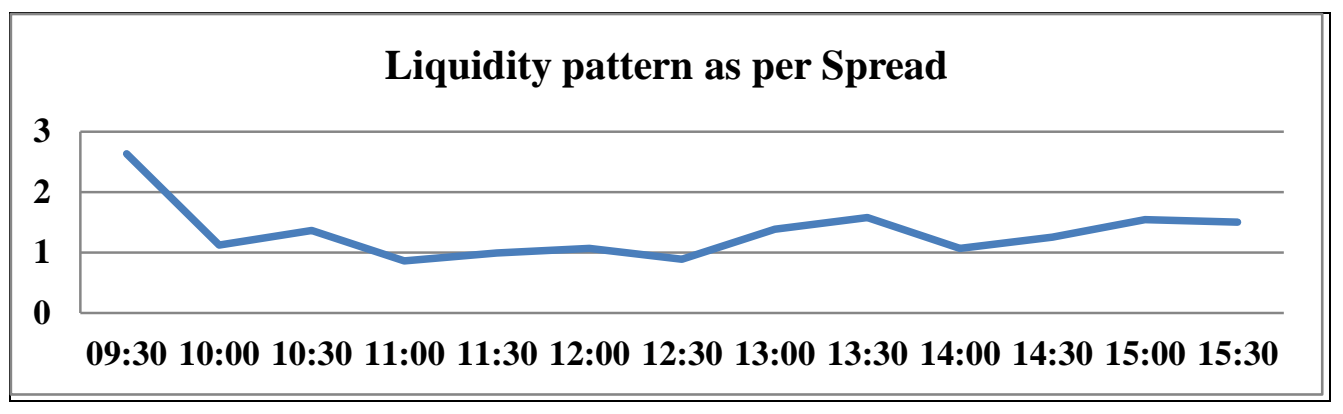

Figure 3. Liquidity pattern as per spread 


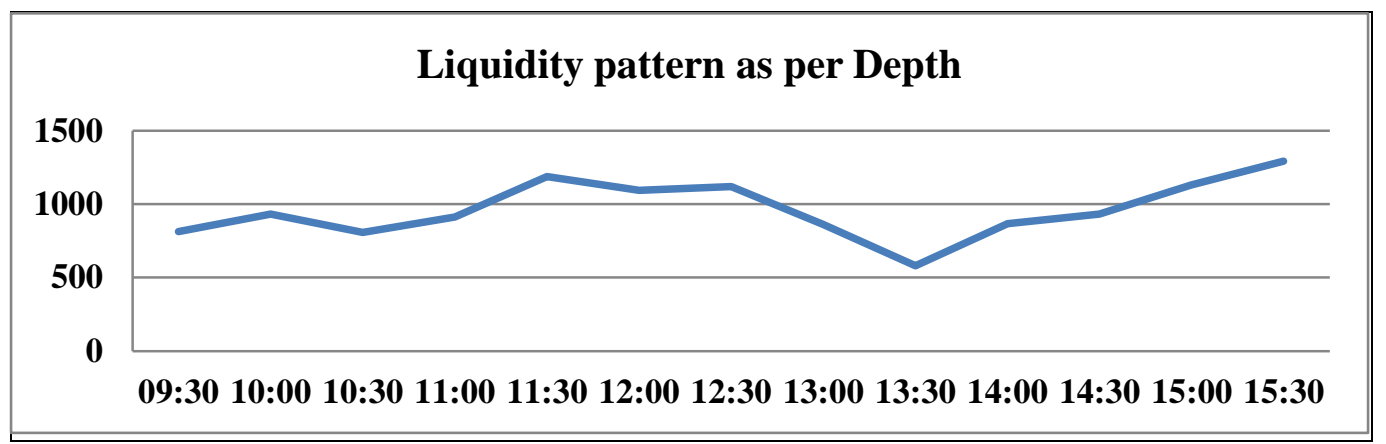

Figure 4. Liquidity pattern as per depth

Table 1. Mean Intraday spread of various sectors at an interval of 30 minutes

\begin{tabular}{ccccccc}
\hline Time & Consumer Goods & Financial Services & Infrastructure & Manufacturing & Non Financial & Pharma \& Chemicals \\
\hline $09: 30$ & 4.008 & 2.653 & 1.350 & 7.404 & 3.644 & 2.420 \\
$10: 00$ & 2.875 & 3.408 & 0.682 & 1.904 & 1.902 & 2.162 \\
$10: 30$ & 2.227 & 3.137 & 0.628 & 2.604 & 3.145 & 1.587 \\
$11: 00$ & 2.393 & 3.462 & 0.547 & 1.469 & 2.576 & 1.672 \\
$11: 30$ & 2.262 & 2.247 & 0.702 & 1.358 & 3.699 & 0.978 \\
$12: 00$ & 1.606 & 1.372 & 0.708 & 1.043 & 4.722 & 2.534 \\
$12: 30$ & 0.956 & 1.181 & 1.361 & 1.981 & 3.618 & 2.776 \\
$13: 00$ & 3.089 & 2.199 & 1.047 & 4.297 & 4.616 & 0.910 \\
$13: 30$ & 3.014 & 2.057 & 0.734 & 8.619 & 2.019 & 2.788 \\
$14: 00$ & 1.747 & 1.778 & 0.488 & 3.922 & 1.424 & 1.479 \\
$14: 30$ & 1.810 & 2.632 & 0.718 & 3.156 & 3.092 & 1.517 \\
$15: 00$ & 1.839 & 2.407 & 1.430 & 5.005 & 2.984 & 1.476 \\
$15: 30$ & 3.171 & 4.369 & 1.032 & 5.039 & 1.554 & 5.866 \\
\hline
\end{tabular}

Table 2. Mean intraday depth of various sectors at an interval of 30 minutes

\begin{tabular}{ccccccc}
\hline Time & Consumer Goods & Financial Services & Infrastructure & Manufacturing & Non Financial & Pharma \& Chemicals \\
\hline 09:30 & 102 & 657 & 794 & 374 & 113 & 144 \\
$10: 00$ & 75 & 622 & 864 & 350 & 109 & 138 \\
$10: 30$ & 91 & 719 & 886 & 376 & 109 & 118 \\
$11: 00$ & 84 & 546 & 889 & 399 & 103 & 102 \\
$11: 30$ & 64 & 645 & 1116 & 488 & 169 & 110 \\
$12: 00$ & 73 & 619 & 1236 & 350 & 128 & 123 \\
$12: 30$ & 81 & 575 & 1114 & 371 & 113 & 123 \\
$13: 00$ & 81 & 523 & 1095 & 379 & 105 & 222 \\
$13: 30$ & 80 & 579 & 998 & 421 & 92 & 141 \\
$14: 00$ & 77 & 624 & 1114 & 296 & 100 & 142 \\
$14: 30$ & 173 & 655 & 1095 & 392 & 113 & 113 \\
$15: 00$ & 93 & 660 & 1175 & 424 & 151 & 137 \\
$15: 30$ & 112 & 697 & 989 & 1012 & & 99 \\
\hline
\end{tabular}

The study assumes that each sector of the economy should have stable liquidity structure. In order to verify this, sectoral stability of liquidity is examined using ADF test. The assumption is based on the fact that there will be continuous flow of information in different sectors of the economy. Also, this may not create unstable pattern of liquidity. The study has found unit root in case of Financial Services sector only, which indicates all other five sectors have stability in liquidity. 
Table 3 . Sectoral liquidity stability

\begin{tabular}{llc}
\hline Sector & ADF Test (P-Value) & Null Hypothesis: Has Unit a root (At 5\% level of significance) \\
\hline Consumer Goods & $-6.3815(0.000)$ & Rejected \\
Financial Service & $-2.5591(0.1045)$ & Accepted \\
Infrastructure & $-4.0754(0.0016)$ & Rejected \\
Manufacturing & $-2.8993(0.0485)$ & Rejected \\
Non-Financial & $-2.60398(0.0951)$ & Rejected \\
Pharma \& Chemicals & $-4.06354(0.0016)$ & Rejected \\
\hline
\end{tabular}

The study has assumed that the volatility of liquidity will be time-varying as information passes through different time period. The time-varying liquidity volatility, for each sector, is examined through the ARCH effect with the null hypothesis of " no ARCH effect" is present. The Table No.2 indicates the presence of time-varying liquidity volatility in cases of Infrastructure and Non-Financial Sectors.

Table 4. ARCH effect of liquidity

\begin{tabular}{lll}
\hline Sector & LM Test (Probability) & Null Hypothesis: No ARCH effect is present \\
\hline Consumer Goods & $\mathrm{LM}=4.01275$ & Accepted \\
& $\mathrm{P}\left(\chi^{2}(5)>4.01275\right): 0.547582$ & \\
Financial Service & $\mathrm{LM}=2.89935$ & Accepted \\
& $\mathrm{P}(\chi 2(5)>2.89935): 0.7155$ & \\
Infrastructure & $\mathrm{LM}=18.3004$ & Rejected \\
& $\mathrm{P}(\chi 2(5)>18.3004): 0.00259$ & \\
Manufacturing & $\mathrm{LM}=6.08871$ & Accepted \\
& $\mathrm{P}(\chi 2(5)>6.08871): 0.29768$ & \\
Non-Financial & $\mathrm{LM}=20.5221$ & Rejected \\
& $\mathrm{P}(\chi 2(5)>20.5221): 0.00099$ & \\
Pharma \& Chemicals & $\mathrm{LM}=0.288465$ & Accepted \\
& $\mathrm{P}(\chi 2(5)>0.288465): 0.99785$ & \\
\hline
\end{tabular}

\subsection{Liquidity Beta: Pattern, Stability \& Granger Non-Causalty}

The liquidty beta is estimated for each of the 30 stocks on a monthly basis over the period of the study. The sectoral beta for each sector is computed using trading volume as weight. Figure 5, which depicts the pattern of liquidity beta for each sector indicates high variabilty of liquidity beta for Pharma \& Chemicals and Non-Financial sectors.

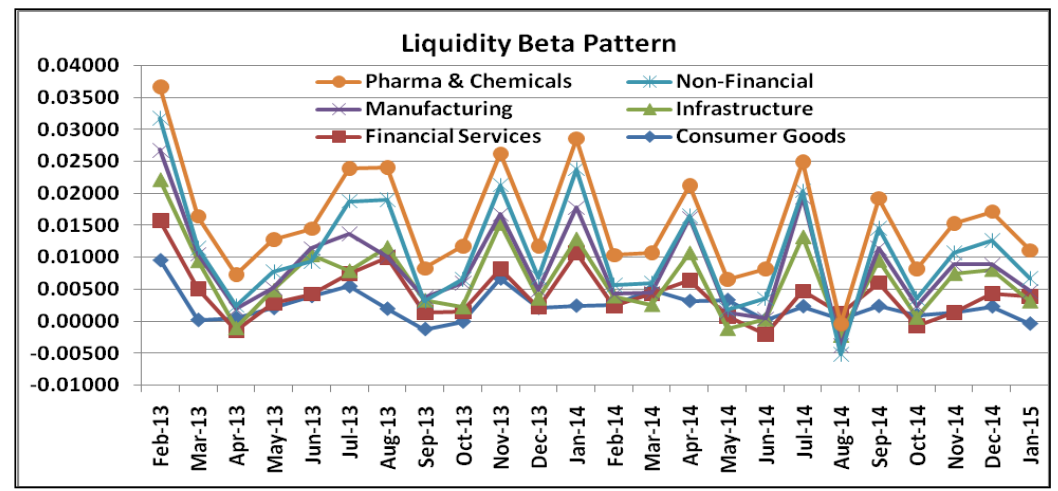

Figure 5. Liquidity beta pattern

The study assumes that each sector of the economy has stable liquidity beta structure. In order to examine the same, liquidity beta put through ADF test. All six sectors of the MidCap rejected the presence of unit root in liquidity beta, thereby indicating the stability of liquidity beta over the sample period (Table 5). 
Table 5. Liquidity beta stability

\begin{tabular}{ccc}
\hline Sector & ADF Test (Probability) & Null Hypothesis: Has Unit a root (At 5\% level of significance) \\
\hline Consumer Goods & $-10.16517(0.000)$ & Rejected \\
Financial Services & $-10.09439(0.000)$ & Rejected \\
Infrastructure & $-9.097326(0.000)$ & Rejected \\
Manufacturing & $-11.95518(0.000)$ & Rejected \\
Non-Financial & $-10.83684(0.000)$ & Rejected \\
Pharma \& Chemicals & $-4.562242(0.0003)$ & Rejected \\
\hline
\end{tabular}

The CAPM beta is influenced by variability in Index returns, which in turn influences the trading volume and liquidity of different sectors. On the basis of the above fact the study assumes that the CAPM beta and Liquidity beta may have causal relationship. The Granger non-causality test indicates that neither CAPM beta nor Liquidity beta causes each other in cases of Financial Services, Manufacturing and Non-Financial sectors. Similarly, Liquidity beta causes CAPM beta in cases of Consumer goods, Infrastructure and Pharma \& Chemicals sectors. However, in case of Pharma \& Chemicals sector, the study doesn’t find causality (Table No. $6)$.

Table 6. Granger non-causality (CAPM beta and liquidity beta)

\begin{tabular}{ccc}
\hline Sector & CAPM Beta $\rightarrow$ Liquidity Beta & Liquidity Beta $\rightarrow$ CAPM Beta \\
\hline Consumer Goods & F-Statistics: $0.7091(0.5874)$ & F-Statistics: $2.7897(0.030)$ \\
Financial Services & Accepted & Rejected \\
Fnfrastructure & F-Statistics: $0.2760(0.8929)$ & F-Statistics: $1.985(0.102)$ \\
& Accepted & Accepted \\
Manufacturing & F-Statistics: $1.03185(0.3943)$ & F-Statistics: $4.7478(0.0014)$ \\
& Accepted & Rejected \\
Non-Financial & F-Statistics: $0.75197(0.5588)$ & F-Statistics: $0.6866(0.6028)$ \\
& Accepted & Accepted \\
Pharma \& Chemicals & F-Statistics: $0.41177(0.7998)$ & F-Statistics: $0.88911(0.4732)$ \\
& Accepted & Accepted \\
& F-Statistics: $2.4807(0.0482)$ & F-Statistics: $2.45157(0.050)$ \\
\end{tabular}

The estimated betas of the 30 MidCap stocks, over the period of 24 months, are put through a GARCH test to understand their time-varying volatility. In the variance equation of $\mathrm{GARCH}$, the study has included Relative Strength Index and Change in Trading Volume as explanatory variables to articulate the time-varying volatility of beta. The estimated GARCH equation (Table 7) indicates the presence of GARCH effect and the significance of both the explanatory variables. The robustness of the GARCH model is tested through residual normality test and ARCH effect.

Table 7. GARCH equation: Dependent: liquidity beta

\begin{tabular}{ccccc}
\hline Variable & Coefficient & Std. Error & Z-statistic & Prob. \\
\hline Constant & 0.002818 & 0.000269 & 10.49243 & 0.0000 \\
\hline & \multicolumn{2}{c}{ Variance Equation } & & Prob. \\
Variable & Coefficient & Std. Error & Z-statistic & 0.0000 \\
Constant & $2.33 \mathrm{E}-05$ & $2.24 \mathrm{E}-06$ & 10.39098 & 0.0006 \\
RESID(-1)^ & 0.149997 & 0.043523 & 3.446413 & 0.0000 \\
GARCH(-1) & 0.599995 & 0.065370 & 9.178426 & 0.0000 \\
Relative Strength Index & $-2.27 \mathrm{E}-07$ & $2.02 \mathrm{E}-08$ & -11.21485 & 0.0343 \\
Change in Trading Volume & $-2.56 \mathrm{E}-06$ & $1.21 \mathrm{E}-06$ & -2.116835 & \\
\hline Jaque-Bera: $570.0738(0.000)$ & & & \\
H0: No ARCH Effect: $\mathbf{L M = 7 . 3 1 5 4 1 ,} \mathbf{P}(\boldsymbol{\chi 2} \mathbf{( 5 )}>\mathbf{7 . 3 1 5 4 1 ) : 0 . 1 9 8 2 1 9}$ \\
\hline
\end{tabular}




\subsection{Liquidity Determinants}

As per various literaure (Ding et al., 2013; Kumar et al., 2001; Söderberg, J., 2008; Næs \& Ødegaard, 2007), the study has considered P-E ratio, P-B ratio, Dividend Yield, Net FII, IIP and G-Sec 10 year yield as determinants of liquidity. The Amihud liquidity proxy of 30 MidCap stocks over the sample period are regressed, in panel data framwork, against the above mentioned independent variables. As per the diagnostic tests (Table 8), panel model is adequate against pooled OLS and fixed effects are consistent as against random effects.

Table 8. Panel diagnostics test

\begin{tabular}{lcc}
\hline \multicolumn{1}{c}{ Null Hypothesis } & Test Statistic & Accepted/Rejected \\
\hline $\begin{array}{l}\text { Pooled OLS is adequate in favor of Fixed Effects Model } \\
\text { Breusch Pagan Test: }\end{array}$ & $\mathrm{F}(29,684)=20.888$ with p-value 2.358 e -75 & $\begin{array}{c}\text { Rejected } \\
\text { Rejected }\end{array}$ \\
$\begin{array}{l}\text { Pooled OLS model is adequate in favor of Random Effects } \\
\text { Model }\end{array}$ & p-value [chi-square(1)>1318.73 & \\
Hausman Test: & $\mathrm{H}=17.836$ with p-value $=$ prob [chi-square(6) $>$ & Rejected \\
Random effects is adequate in favor of Fixed effects Model & 17.836 ] $=0.00665$ & \\
\hline
\end{tabular}

The fixed effects regression (Table 9) indicates P-E ratio, P-B ratio, Dividend Yield and IIP are significant determinants which influence the liquidity in the MidCap sector.

Table 9. Fixed-effects: Dependent variable-liquidity

\begin{tabular}{|c|c|c|c|c|}
\hline & Coefficient & Std. Error & t-ratio & p-value \\
\hline Constant & 0.24825 & 0.897766 & 0.2765 & 0.78223 \\
\hline Price-Earning & -0.00205773 & 0.0010456 & -1.9680 & 0.04947 \\
\hline Price-Book & 0.125594 & 0.0251877 & 4.9863 & $<0.00001$ \\
\hline Dividend Yield & -0.253616 & 0.0625278 & -4.0561 & 0.00006 \\
\hline Net FII & $-3.31421 \mathrm{e}-06$ & $5.88994 \mathrm{e}-06$ & -0.5627 & 0.57383 \\
\hline IIP & 1.88776 & 0.868354 & 2.1740 & 0.03005 \\
\hline GSec-10 Yr Yield & 0.134618 & 0.107253 & 1.2551 & 0.20985 \\
\hline Adjusted R-squared: 0.48225 & & \multicolumn{3}{|l|}{ Null hypothesis: } \\
\hline $\mathbf{F}(\mathbf{3 5}, \mathbf{6 8 4}): 20.134(1.08 \mathrm{e}-82)$ & & \multicolumn{3}{|c|}{ The groups have a common intercept } \\
\hline Durbin-Watson: 1.7845 & & \multicolumn{3}{|c|}{$\mathbf{F}(\mathbf{2 9}, \mathbf{6 8 4}): 20.8879$} \\
\hline & & \multicolumn{3}{|c|}{ p-value: $(\mathbf{F}(\mathbf{2 9}, \mathbf{6 8 4})>\mathbf{2 0 . 8 8 7 9}): 2.25 \mathrm{e}-075$} \\
\hline
\end{tabular}

\subsection{Liquidity Premium \& Asset Pricing}

Stocks have been sorted in decreasing order of liquidity. The study constructed 72 portfolios with one month formation and one month holding period. The return differential between the highest and lowest liquidity portfolio represents "Liquidity Hedging Portfolio (LHP)" return. The Figure no.6 indicates the co-movement of LHP premium and portfolio return.

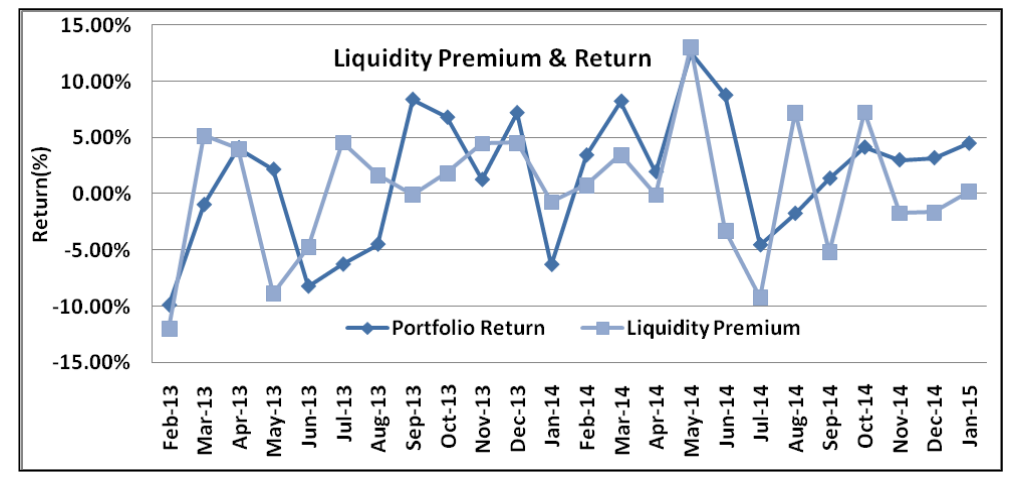

Figure 6. Liquidity premium and return 
The study has also estimated premium for SMB (by arranging the stocks as per size), HML (by arranging the stocks as per Book value) and WML (by arranging the stocks as per momentum).

Table 10. Dependent variable: Excess portfolio returns

\begin{tabular}{ccccc}
\hline & Coefficient & Std. Error & t-ratio & p-value \\
\hline Constant & -0.0252394 & 0.0148784 & -1.6964 & 0.10704 \\
LHP & -0.224064 & 0.119337 & -1.8776 & 0.07674 \\
SMB & 0.180147 & 0.161769 & 1.1136 & 0.28010 \\
HML & -0.392873 & 0.105789 & -3.7138 & 0.00159 \\
WML & 0.288561 & 0.159168 & 1.8129 & 0.08655 \\
EMR & 0.843441 & 0.17741 & 4.7542 & 0.00016 \\
\hline Adjusted R-squared: 0.7228 & & & \\
P-value(5,18): 22.624 (3.50e-07) & Durbin-Watson: 2.1283 & & \\
\hline
\end{tabular}

Following Carhart four factor model (1997), the study has estimated the asset pricing with LHP as the fifth factor. The estimated results (Table 10) indicate the significance of LHP, WML, EMR and HML (at 10\% significance level) in asset pricing.

The studies of Chikore et al. (2014) and Sum (2014) empirically examined the causal relation between stock returns and liquidity. This study also tests the same in different sectors of the Indian economy (Table 11). The results suggest the acceptance of Granger non-causality between returns and liquidity across sectors except Financial Services where return Granger causes liquidity.

Table 11. Granger non-causality (return and liquidity)

\begin{tabular}{lll}
\hline Sector & Return Liquidity & Liquidity $\longrightarrow$ Return \\
\hline Consumer Goods & F-Statistics: $0.85203(0.4954)$ & F-Statistics: $1.40987(0.2356)$ \\
& Accepted & Accepted \\
Financial Services & F-Statistics: $3.16707(0.0167)$ & F-Statistics: $2.42850(0.0522)$ \\
& Rejected & Accepted \\
Infrastructure & F-Statistics: $1.32060(0.2670)$ & F-Statistics: $0.86689(0.4864)$ \\
Manufacturing & Accepted & Accepted \\
& F-Statistics: $0.15815(0.9589)$ & F-Statistics: $1.39083(0.2420)$ \\
Non-Financial & Accepted & Accepted \\
& F-Statistics: $2.17787(0.0763)$ & F-Statistics: $0.87763(0.4800)$ \\
Pharma \& Chemicals & Accepted & Accepted \\
& F-Statistics: $0.99925(0.4114)$ & F-Statistics: $0.69180(0.5992)$ \\
\hline
\end{tabular}

\section{Conclusion}

Against the notion, the study indicates Indian MidCap stocks have varying degree of liquidity. Pharma \& Chemicals sector has higher level of liquidity compared to consumer goods sector which is almost static during the studied period. The L-shaped for the intraday pattern indicates the declining trend of liquidity for the MidCap stocks with the business closing hours. The study has observed instability in the liquidity pattern of Financial Services Sector. Other five sectors of the MidCap have stable liquidity pattern. The study also observed that P-E ratio, P-B ratio, Dividend Yield and Index of Industrial Production are the major determinants of liquidity of MidCap stocks.

The study introduced the concept of liquidity beta and found that MidCap stocks returns are sensitive to liquidity variation. The study has also found stability of liquidity beta across the six sectors of the MidCap over the sample period. The study observed that CAPM and liquidity betas are independent in cases of Financial Services, Manufacturing and Non-Financial Sectors. The liquidity betas of MidCap stocks have time-varying volatility and Relative Strength Index (RSI) and Change in Trading Volume, as exogenous variables, in describing the time-varying volatility of beta. The study observed that MidCap stocks are claiming liquidity premium and also influencing the asset pricing along with WML, HML and EMR factors. 


\section{References}

Acharya, V. V., \& Pederson, L. H. (2005). Asset pricing with liquidity risk. Journal of Financial Economics, 77, 375-410. http://dx.doi.org/10.1016/j.jfineco.2004.06.007

Amihud, Y. (2002). Illiquidity and stock returns: Cross section and time-series effects. Journal of Financial Markets, 5(1), 31-56. http://dx.doi.org/doi:10.1016/S1386-4181(01)00024-6

Amihud, Y., \& Mendelson, H. (1980). Dealership Market: Market making with inventory. Journal of Financial Economics, 8, 31-53. http://dx.doi.org/10.1016/0304-405X(80)90020-3

Amihud, Y., \& Mendelson, H. (1986). Asset pricing and the bid-ask spread. Journal of Financial Economics, 17, 223-249. http://dx.doi.org/10.1016/0304-405X(86)90065-6

Baber, A., Brandt, M. W., Cosemans, M., \& Verardo, M. (2012). Ownership Crowded with Style: Institutional Investors, Liquidity, and Liquidity Risk. Retrieved from https://faculty.fuqua.duke.edu/ mbrandt/papers/working/ownership.pdf

Baker, K. (1996). Trading Location and liquidity-An Analysis of US dealer and Agency Markets for Common Stocks. Financial Markets, Institutions and Instruments, 5(4).

Bali, T. G., Peng, L., Shen, Y., \& Tang, Y. (2013). Liquidity Shocks and Stock Market Reactions. The Review of Financial Studies, 27(5), 1434-1485. http://dx.doi.org/10.1093/rfs/hht074

Bernstein, P. L. (1987). Liquidity, Stock Markets, and Market Makers. Financial Management, 16(2), 54-62. http://dx.doi.org/10.2307/3666004

Carhart M. (1997). On persistence in mutual fund performance. Journal of Finance, 52, 57-82. http://dx.doi.org/10.1111/j.1540-6261.1997.tb03808.x

Chang, Y. Y., Faff, R., \& Hawang, C. Y. (2009). Liquidity and stock returns in Japan: New Evidence. Pacific Basin Finance Journal, 18, 90-115. http://dx.doi.org/10.1016/j.pacfin.2009.09.001

Chikore, R., Nkomo, D., Gachira, W., \& Chiwanja, W. (2014). Stock Liquidity and Returns: Evidence from Zimbabwe Stock Exchange. Interdisciplinary Journal of Contemporary Research in Business, 6(3). Retrieved from http://euabr.com/ijcrbjul14/20-35jul14.pdf

Chordia, T., Roll, R., \& Subrahmanyam, A. (2000). Commonality in liquidity. Journal of Financial Economics, 56, 3-28. http://dx.doi.org/10.1016/S0304-405X(99)00057-4

Chordia, T., Roll, R., \& Subrahmanyam, A. (2001). Common determinants of Liquidity and Trading. The Research Foundation of AIMR (CFA Institute).

Chordia, T., Roll, R., \& Subrahmanyam, A. (2001). Market liquidity and Trading Activity. Journal of Finance, 56(2), 501-530. http://dx.doi.org/10.1111/0022-1082.00335

Chordia, T., Roll, R., \& Subrahmanyam, A. (2003). Determinants of daily fluctuations in liquidity and trading activity. Cuadernos de Economía, 120(40), 728-751. http://dx.doi.org/10.4067/S0717-68212003012100046

Chordia, T., Sarkar, A., \& Subrahmanyam, A. (2005). The Joint Dynamics of Liquidity, Returns, and Volatility across Small and Large Firms. Federal Reserve Bank of New York Staff Reports, 207. Retrieved from http://www.newyorkfed.org/research/staff_reports/sr207.pdf

Ding, M, Nilsson, B., \& Suardi, S. (2013). Foreign Institutional Investors and Stock Market Liquidity in China: State Ownership, Trading Activity and Information Asymmetry. Knut Wicksell Working Paper, 2013, p. 14.

Eleswarapu, V. R., \& Reinganum, M. R. (1993). The seasonal behavior of liquidity premium in Asset pricing. Journal of Financial Economics, 34, 373-386. http://dx.doi.org/10.1016/0304-405X(93)90032-7

Faff, R., Chang, Y. Y., \& Hwang, C. Y. (2010). Liquidity and stock returns in Japan: New evidence. Pacific-Basin Finance Journal, 18, 90-115. http://dx.doi.org/10.1016/j.pacfin.2009.09.001

Fu, F. (2012). Liquidity Variation and the Cross Section of Stock Returns. Research collection Lee Kong School of Business. Retrieved from http://ink.library.smu.edu.sg/lkcsb_research/3267

Gatchav, V. A., Spindt, P. A., \& Banerjee, S. (2005). Stock Market Liquidity and Firm Dividend Policy. Retrieved from http://www.tulane.edu/ gatchev/Liquidity_and_Dividends.pdf

Goyenko, R. Y., \& Ukhov, A. D. (2009). Stock and Bond Market Liquidity: A Long-Run Empirical Analysis. Journal of Financial and Quantitative Analysis, 44(1), 189-212. http://dx.doi.org/10.2139/ssrn.669942

Hagstromer, B., Hansson, B., \& Nilsson, B. (2013). Illiquidity frictions and asset pricing anomalies. Retrieved 
from http://www.efmaefm.org/0EFMAMEETINGS/EFMA\%20ANNUAL\%20MEETINGS/2014-Rome /papers/EFMA2014_0481_fullpaper.pdf

Hasbrouck, J. (2009). Trading costs and returns for US equities: Estimating effective costs from daily data. Journal of Finance, 64, 1445-1477. http://dx.doi.org/10.1111/j.1540-6261.2009.01469.x

Hubers, T. (2012). Liquidity and Asset Pricing: Evidence for the London Stock Exchange. Retrieved from http://arno.uvt.nl/show.cgi?fid=129643

Hui, B., \& Heubel, B. (1984). Comparative liquidity Advantages among Major U.S. Stock Markets. Lexington, MA, Data Resources, Inc.

Jacoby, G., \& Zheng, S. X. (2010). Ownership dispersion and market liquidity. International Review of Financial Analysis, 19, 81-88. http://dx.doi.org/ 10.1016/j.irfa.2010.01.008

Kim, O., \& Verrecchia, R. E. (1994). Market liquidity and volume around earnings announcements. Journal of Accounting and Economics, 17(1-2), 41-67. http://dx.doi.org/10.1016/0165-4101(94)90004-3

Köksal, B. (2012). An Analysis of Intraday Patterns and Liquidity on the Istanbul Stock Exchange. Central Bank of the Republic of Turkey, Research and Monetary Policy Department Working paper, No. 12/26.

Krishnan, R., \& Mishra, V. (2013). Intraday Liquidity Patterns in Indian Stock Market. Journal of Asian Economics, 28, 99-114. http://dx.doi.org/ 10.1016/j.asieco.2013.05.005

Kumar, M., Bhole, L. M., \& Saudagaran, S. M. (2001). The impact of International Listings on Liquidity: Evidence from the Indian Stock Market. Vikalpa, 26(4), 35-50.

Lipson, M. L., \& Mortal, S. (2009). Liquidity and Capital Structure. Journal of Financial Markets, Forthcoming. Darden Business School Working Paper. Retrieved from http://ssrn.com/abstract=887413

Liu, C., Agarwal, S., Faircloth, S., \& Rhee, S. G. (2009). Why do foreign investors underperform domestic investors in trading activities? Evidence from Indonesia. Journal of Financial Markets, 12(1), 32-53. http://dx.doi.org/10.1016/j.finmar.2008.04.001

Martinez, M. A., Nieto, B., Rubio, G., \& Tapia, M. (2005). Asset pricing and systematic liquidity risk: An empirical investigation of the Spanish stock market. International Review of Economics and Finance, 14, 81-103. http://dx.doi.org/10.1016/j.iref.2003.12.001

Næs, R. (2004). Ownership Structure and Stock Market Liquidity. Working Papers from Norges Bank, ANO $2004 / 6$.

Narayan, P. K., \& Zheng, X. (2011). The relationship between liquidity and returns on the Chinese stock market. Journal of Asian Economies, 22, 259-266. http://dx.doi.org/10.1016/j.asieco.2011.02.005

Nguyen, D., Mishra, S., Prakash, A., \& Ghosh, D. (2007). Liquidity and asset pricing under the three-moment CAPM paradigm. Journal of Financial Research, 30, 379-398. http://dx.doi.org/10.1111/j.1475-6803.2007.00219.x

Pastor, L., \& Stambaugh, R. F. (2003). Liquidity Risk and Expected Stock Returns. Journal of Political Economy, 111, 642-685. http://dx.doi.org/10.1086/374184

Peter, G., Amador, O. F., Gächter, M., \& Larch, M. (2013). Does monetary policy determine stock market liquidity? New evidence from the euro zone. Journal of Empirical Finance, 21, 54-68. http://dx.doi.org/10.1016/j.jempfin.2012.12.008

Sarr, A., \& Lybek, T. (2002). Measuring liquidity in financial markets. IMF Working Paper, WP/02/232, December.

Sharma, L. (2005). Ownership Structure and Stock Liquidity-Evidence from Indian Market. Retrieved from http://www.nseindia.com/content/press/LS_mar2005.pdf

Sioud, O. B., Hmaied, D. M., \& Grar, A. (2006). Dynamics of Market Liquidity of Tunisian Stocks: An Analysis of Market Resiliency. Electronic Markets, 16(2). http://dx.doi.org/10.1080/10196780600643977

Söderberg, J. (2008). Do Macroeconomic Variables Forecast Changes in Liquidity? An Out-of-Sample Study on the Order-Driven Stock Markets in Scandinavia. Conference on Liquidity: Concepts and Risks, 17-18 October, 2008.

Sum. (2014). Stock Market Returns and Liquidity: Dynamic Relationships and Causality. Journal of Trading, 9(1), 34-40. http://dx.doi.org/10.2139/ssrn.2177332 
Tissaoui, K. (2012). The Intraday Pattern of Trading Activity, Return Volatility and Liquidity: Evidence from the Emerging Tunisian Stock Exchange. International Journal of Economics and Finance, 4(5). http://dx.doi.org/10.5539/ijef.v4n5p156

Trzcinka, C. A., Goyenko, R. Y., \& Holden, C. W. (2009). Do liquidity measures measure liquidity? Journal of Financial Economics, 92, 153-181. http://dx.doi.org/10.1016/j.jfineco.2008.06.002

Trzcinka, C. A., Goyenko, R. Y., Holden, C. W., \& Lundblad, C. T. (2009). Horse races of Monthly and Annual Liquidity Measures. $\quad$ Retrieved from http://public.kenan-flagler.unc.edu/faculty/lundblac/Liquidity_GHLT.pdf

Vu, V., Chai, D., \& Do, V. (2014). Empirical test on the Liquidity-adjusted Capital Asset Pricing Model. Retrieved from http://ssrn.com/abstract=2388035

Wang, J. (2007). Foreign equity trading and emerging market volatility: Evidence from Indonesia and Thailand. Journal of Development Economics, 84(2), 798-811. http://dx.doi.org/10.1016/j.jdeveco.2006.05.001

Watanabe, A., \& Watanabe, M. (2008). Time-Varying Liquidity Risk and the Cross Section of Stock Returns. Review of Financial Studies, 21(6), 2449-2486. http://dx.doi.org/10.1093/rfs/hhm054

Wei, C. (2010). Do foreign investors improve stock liquidity? University of Texas Working paper. Retrieved from https://webspace.utexas.edu/cw2932

Yaghoobnezhad, A., Roodposhti, F. R., \& Zabihi, A. (2011). The Study of Relationship between Institutional Ownership and Stock Liquidity in Tehran Stock Exchange, J. Basic. Appl. Sci. Res., 1(12), 2736-2742.

Retrieved from http://textroad.com/Old\%20version/pdf/JBASR/J.\%20Basic.\%20Appl.\%20Sci.\%20 Res.,\%201(12)2736-2742,\%202011.pdf

\section{Copyrights}

Copyright for this article is retained by the author(s), with first publication rights granted to the journal.

This is an open-access article distributed under the terms and conditions of the Creative Commons Attribution license (http://creativecommons.org/licenses/by/3.0/). 